\title{
Private Label Marketing Performance: An Analysis of Historical Trends Using Theories of Cumulative Change and Punctuated Equilibrium
}

\author{
Dr Ranga Chimhundu \\ School of Management and Marketing, Faculty of Business, University of Southern Queensland \\ Toowoomba, QLD 4350, Australia \\ Tel: 61-7-4687-5759Ｅ-mail: Ranga.Chimhundu@usq.edu.au
}

Received: February 10, $2011 \quad$ Accepted: March 3, $2011 \quad$ doi:10.5539/ijbm.v6n8p58

\begin{abstract}
The article analyses historical trends in the development of private label and national brands using gradualist and punctuated evolutionary theories. The purpose of the article is to unveil patterns that would give fresh insights into the growth of private label in relation to national brands. The study makes use of qualitative and quantitative data on private label historical trends in four countries. While the literature has depicted private label share growth as gradual and incremental in nature, this study found that it is only on average that the yearly increase in private label share could fit the gradualist description. In reality, the actual process is not always gradual. Often, a period of gradual change and/or stability is followed by a punctuation, and vice-versa. The applicability of punctuated equilibrium theory to the growth and market share development of private label is supported by the results of this study.
\end{abstract}

Keywords: Private label, National brand, Private label trends, Cumulative change, Gradualist theory, Punctuated equilibrium, Punctuated evolution, Evolutionary theory

\section{Introduction}

FMCG (fast moving consumer goods) product categories in many countries now have private label brands participating in them, alongside national brands. National brands are owned by manufacturers and private label brands are owned by the retail chains. Private label brands have been described as a global phenomenon (ACNielsen, 2005; Herstein and Gamliel, 2004) and these brands are increasingly challenging national brands in the market place. National brands are still dominant though, but it is common knowledge to most consumer packaged goods enthusiasts that the private label is continuing to gain inroads in territories that traditionally belonged to the national brand. In this regard, academic researchers have shown an interest in private label activity and growth patterns in consumer packaged goods (e.g. Chimhundu, Hamlin and McNeill, 2008; Lamey, Deleersneyder, Dekimpe and Steenkamp, 2007). This article seeks to advance the academic literature in the area of the growth patterns of private label through the application of two competing theories, cumulative change and punctuated equilibrium, to explain private label and national brand development patterns. Of special interest in this regard are market share performance and trends.

\section{The Concept of Equilibrium}

Equilibrium has been defined as a situation in which opposing forces or influences are in a state of balance and under control (Hornsby, 1998). The concept of equilibrium has been applied to a variety of study fields such as biology, physical science, geology, psychology, economics, and business. Such application and related studies have adopted either quantitative or qualitative approaches. Studies on equilibrium situations related to price, supply and demand have largely been quantitative in nature. Some studies on equilibrium situations related to organisational change have been qualitative in nature (e.g. Katsanis and Pitta, 1995), while others have adopted mixed methods (e.g. Romanelli and Tushman, 1994). The study approach adopted has largely depended on the nature of issues being tackled. The concept of equilibrium is deemed to be relevant to studies on the state of balance between private label and national brands, and the related market share development patterns. It is increasingly becoming evident that private label is here to stay and that the existence of both private label and national brands side by side will be a permanent feature of the grocery sector. A number of stakeholders that include channel participants and researchers would therefore take an interest in seeking to understand better, the variables that have an influence on the balance between the two types of brands as well as the actual process of balancing these brands. Taking private label and national brands as opposing forces given their ownership and competitive situation, the concept of equilibrium is judged to be appropriate to employ in the analysis of the market share patterns of these two types of brands. While it is acknowledged that there is a wealth of literature on equilibrium studies, this article mainly focuses on gradualist and punctuated evolutionary theories, details of 
which are covered in the next section.

\section{Gradualist Theory vs. Punctuated Equilibrium Theory}

The application of theories derived from outside the business field to marketing is not unusual. There is a history of application of biological models in the field of marketing, dating as far back as 1957. The product life cycle model was one of the first to be introduced and cemented into the marketing field (Katsanis and Pitta, 1995). Gradualist and punctuated equilibrium theories also have their roots in biological models. The gradualist theory of change has its origins in Darwin's model of evolution, which takes evolution as a slow, cumulative, incremental process. The theory became pervasive; was later applied to a variety of fields ranging from geological erosion to skill acquisition (Gersick, 1991), and can also be used to explain the change that takes place in organisational settings.

In the field of evolutionary biology, natural historians, Eldridge and Gould (1972) proposed a different view of evolution termed punctuated equilibrium, thus challenging Darwinian gradualism. They postulated that lineages experience little change over most of their history, and that new species arise through abrupt, revolutionary punctuations. According to Gersick (1991), similar, empirically derived theories in a variety of fields have echoed this theory. For instance, in the field of innovation, Abernathy and Utterback (1982) have made a contrast between evolutionary and radical innovation in industry. In the field of organisational management, Romannelli and Tushman (1994) adapted the punctuated equilibrium model, empirically tested it and found that it was consistent with organisational change. The results of their study demonstrated that "revolutionary transformation, as predicted by the punctuated equilibrium model, is a principal means by which organisations fundamentally alter their systems, strategies and structures" (p. 1159). In this regard, the essence of punctuated equilibrium theory is that "relatively long periods of stability (equilibrium), are punctuated by compact periods of qualitative, metamorphic change (revolution)" (Gersick, 1991, p. 12). In addition, Katsanis and Pitta (1995) applied punctuated equilibrium theory to product management and showed that the theory is useful in explaining changes that the product management system has been experiencing, and changes that it continues to undergo. The functioning of the punctuated equilibrium paradigm is based on three key components, namely; deep structure, equilibrium periods, and revolutionary periods. These are briefly discussed next according to a number of authors (Gersick, 1991; Katsanis and Pitta, 1995; Tushman and Romannelli, 1985).

Deep structure: - Also termed underlying structure or underlying order, this is the order that is in place during periods of equilibrium; the order that limits change and promotes stability. It consists of core beliefs, core values, culture, operating routines, control systems, basic internal structure/ organisational structure (formal and informal), resources, technology, products, markets, competitive timing, core competencies and distributions of power. Deep structure is essentially the design and function of the organisation and it does interact with the external environment.

Equilibrium: - During equilibrium periods, activity patterns of the organisation remain the same and the deep structure is preserved. Incremental adjustments can occur to compensate for internally-generated or externally-generated environmental disturbances, but without changing the deep structure. Barriers to change include loss of opportunities and interdependence among networks.

Revolution: - "It is usually changes in the internal and/or external environment that cause revolutionary punctuations" (Katsanis and Pitta, 1995, p. 52). "Periods of revolution cause deep structures to disassemble, reconfigure, and undergo wholesale transformation ... Revolutionary periods close rapidly once a new deep structure is found" (Katsanis and Pitta, 1995, p. 52). According to Romanelli and Tushman's (1994) empirical test, changes in the short-term performance of an organisation do not cause revolutionary punctuations. Two types of revolution, both short in duration, have been identified (Katsanis and Pitta, 1995) as reorientation and recreation. "During reorientation, strategies, power, structure and systems are fundamentally transformed. Change is discontinuous. Recreations are reorientations which involve change in core values and are the most radical revolutions" (p. 51).

In summary, on the one hand, punctuated equilibrium theory involves a rapid change over a short period of time (revolution), which is followed by a state of equilibrium. The period of equilibrium can either experience no change at all or can be characterised by slow, incremental change. The process can also be a one-off or can happen over and over again, over time. On the other hand, gradualist theory involves consistently slow/gradual, incremental change throughout. In this regard, the issue of what pattern private label market share development adopts in the consumer packaged goods industry in relation to national brands can best be assessed through the analysis of historical data; both quantitative and qualitative.

\section{Research Questions}

The objective of the study is centred on establishing the growth patterns of private label share in relation to national brands in the context of the two competing theories, i.e. gradualist theory and punctuated evolution theory. The research questions are: - Does private label market share development follow the gradualist or the punctuated evolution pattern? What would the theoretical explanation for the relevant pattern be? These questions are important because the answers to them are an incremental step in building the academic literature 
that would eventually enable the prediction of changes in private label market share development.

\section{Methodology}

The research made use of historical private label data from four countries as follows: - Qualitative data describing USA private label historical trends from 1840 to 1950 were gathered from a number of sources. Quantitative data for this period were however hard to come by. Explanations for the trends were largely derived from the academic literature (e.g. Fitzell, 1998; Herstein and Gamliel, 2004), and the trends were then interpreted using gradualist and punctuated evolutionary theories. Quantitative and qualitative data on the UK (1962 to 2005), USA (1982-2005), Australia (1987-2005) and New Zealand (1992-2005) trends were derived from academic sources (e.g. Baden-Fuller, 1984; Fernie and Pierrel, 1996; Herstein and Gamliel, 2004) and industry sources (e.g. ACNielsen 2002, 2005), Coriolis Research (2002), and the Private Label Manufacturers' Association. Trends were established using time series analysis, and the trends were then interpreted using gradualist and punctuated evolutionary theories. For ease of presentation of the detailed stage by stage explanations, the analysis largely used tabular format. It should be noted that, with regard to the quantitative aspects, which are conspicuous by their absence in this article, parts of the four graphs that gave rise to the explanations in the tables had been prepared previously for other research purposes and were not expected to be republished here. Other than that, the purpose, theories and content of this article are entirely different.

A limitation of the study however, is that of two or so gaps that could not be filled in the analysis tables as a result of inadequate historical data. Nevertheless, this does not render the tables incomplete because the bulk of the required information is in there. One other limitation still linked to the availability of historical data is that of the differences in the years covered for each country. The varying range is due to the fact that the research went by data availability.

\section{Analysis and Discussion of Retailer Brand Historical Trends}

Tables 1 and 2 systematically summarise the descriptions of private label share trends by specific time period, and also outline theoretical classifications of each, causes of the trends, and the relevant theoretical explanations which are indeed interpreted in the context of gradualist and punctuated evolutionary theory (Refer to Tables 1 and 2). As can be seen in each of the two tables, the first column on the left, i.e. "Country and Year(s)" shows the specific time period(s) covered by the trends. In the second column (Description of Private Label Share Trend) the trends are described based on the analysed quantitative and/or qualitative data. A quick run through the second column of both tables shows each of the characteristic trends at different points in time, with one specific trend being replaced by another as the years progressed. The third column (Theoretical Classification) describes the trends in the context of the theories, resulting in the relevant theoretical classifications. The fourth column (Cause of Trend) discusses why these trends occurred. The reasons for the specific trends are largely derived from the academic literature. From the historical accounts, a large number of factors have been seen to affect the trends at different points in time. These factors include; economic booms, economic downturns, relaxation of industry regulations, the innovative activities of private label, entrepreneurial activities, improvements in transportation systems, media innovation, world wars, market saturation, competition, consumer inertia, and retail consolidation. The factors have not been stated in any particular order. These factors have been seen to affect private label share evolution, and they range from external environmental factors such as economic depressions, which are not controllable by companies, to internal company factors such as the chosen business strategy, which are controllable.

The last column on the right (i.e. Theoretical Explanation) provides the theoretical explanation for the theoretical classification in the second column. Characteristic elements of gradualist theory or punctuated equilibrium theory are used as the framework of analysis. As discussed in the literature section, punctuated equilibrium theory consists of three key components, which are, underlying order (deep structure), equilibrium periods, and revolutionary periods. A period of equilibrium can either experience no change at all or can be characterised by slow, incremental change. A period of revolution is characterised by rapid change over a short period of time. Gradualist theory involves consistently slow, incremental/gradual change throughout. The causes of the trends therefore are made to feed into the theoretical explanation in a way that generates the theoretical classification. With regard to theoretical classification, as outlined and discussed in the tables, private label share trends have exhibited the following characteristics: punctuated evolution followed by a gradual upward trend; punctuated evolution followed by a sharp upward trend; punctuated evolution followed by a gradual downward trend; and punctuated evolution followed by either very minimal or no change at all. Based on the classifications unveiled, the study argues that the theory of punctuated equilibrium is a more appropriate theory to explain the growth and market share development of private label over time than the gradualist theory.

In absolute terms however, private label share development seems to be a slow, incremental process since the period of gradual change and/or stability that follows each punctuation tends to slow down the growth process on average. The fact that on average, the yearly increase in private label share is gradual is supported by the academic literature (e.g. Hoch, Montgomery and Park, 2002) and the trade literature (e.g. Coriolis Research, 2002), but this does not in any way mean that the actual process itself is gradual throughout, as has been 
demonstrated by the historical trends. The applicability of the punctuated equilibrium evolutionary theory to the historical development of private label brands has been demonstrated and supported by qualitative and quantitative historical data. An incremental contribution to knowledge is therefore achieved through the application of a new theory to private label share trends and demonstrating the validity of the theory using historical data. Another contribution has been the re-conceptualisation of a fairly recent five-era framework (Herstein and Gamliel, 2004) on the history of retailer brands using the theory of punctuated equilibrium, as outlined in the tables. While the five eras (Herstein and Gamliel, 2004) are not explicitly outlined in the respective tables, most of the causes of the trends in the tables are derived from the framework.

\section{Conclusion}

The article has analysed historical trends in the development of private label and national brands using cumulative (gradualist) and punctuated equilibrium (punctuated evolution) theories. Market share performance has been taken as a marketing performance measure in the balance and development of private label and national brands. If private label is, for instance, gaining share at the expense of national brands or vice-versa, this would be taken as an indicator of superior marketing performance on the part of one type of brand in relation to the other brand. The pattern of share gain or loss or stability was therefore of interest in this study, and it had to be presented as a trend that would be interpreted using relevant theories. While the literature has depicted private label share growth as gradual and incremental in nature, the study has unveiled fresh insights related to patterns in the growth and market share development of private label. As established, it is only on average that the annual private label share growth is gradual. It has been noted that periods of equilibrium represented by either slow, gradual change or no change at all are followed by punctuations. The results of the study therefore support the applicability of punctuated equilibrium theory to the growth and market share development of private label, and that is the main contribution of this paper. It is important that academic researchers, consumer packaged goods manufacturers, members of the distribution channels, and business analysts get a true picture of aspects related to the development of private label in relation to national brands as private label has become and will continue to be a permanent feature of the FMCG sector. Since this research went by data availability at the time and thus leading to differences in the years covered for each country, further research could try to cover a standard time period for the countries concerned, and this would mean additional data collection. Future research could also address private label share trends in countries other than the four covered in this research in order to establish relevant patterns in marketing performance in relation to national brands.

\section{References}

Abernathy, W., \& Utterback, J. (1982). Patterns of industrial innovation. In M. Tushman \& W. Moore (Eds.), Readings in the Management of Innovation (pp. 97-108). Boston, MA: Pitman.

ACNielsen. (2002). Market Information Digest: Book 1 - General Trade Information. Auckland: ACNielsen NZ.

ACNielsen. (2005). The Power of Private Label: A Review of Growth Trends Around the World. New York, NY: ACNielsen.

Baden-Fuller, C. W. F. (1984). The changing market share of retail brands in the UK grocery trade 1960-1980. In C. W. F. Baden-Fuller (Eds), The Economics of Distribution (pp. 513-526). Milan: Franco Angeli.

Chimhundu, R., Hamlin, R. P., \& McNeill, L. (2010). Impact of manufacturer brand innovation on retailer brands. International Journal of Business and Management, 5(9), 10-18.

Coriolis Research. (2002). Responding to Private Label in New Zealand. Auckland: Coriolis Research.

Eldridge, N., \& Gould, S. (1972). Punctuated equilibria: An alternative to phyletic gradualism. In T. J. Schopf (Eds.), Models in Paleobiology (pp. 82-115). San Francisco: Freeman, Cooper \& Co.

Fernie, J., \& Pierrel, F. R. A. (1996). Own branding in UK and French grocery markets. Journal of Product and Brand Management, 5(3), 48-59.

Fitzell, P. B. (1982). Private Labels, Store brands and Generic Products. Westport, Connecticut: Avi Publishing Company.

Gersick, C. J. G. (1991). Revolutionary change theories: A multilevel exploration of the punctuated equilibrium paradigm. Academy of Management Review, 16(1), 10-36.

Herstein, R., \& Gamliel, E. (2004). An investigation of private branding as a global phenomenon. Journal of Euromarketing, 13(4), 59-77.

Hoch, S. J., Montgomery, A. L., \& Park, Y. H. (2002). Why private labels show long-term market evolution. Marketing Department Working Paper, University of Pennsylvania.

Hornsby, A. S. (1998). Oxford Advanced Learner's Dictionary of Current English. (5 ${ }^{\text {th }}$ ed.). Oxford: Oxford University Press.

Katsanis, L. P., \& Pitta, D. A. (1995). Punctuated equilibrium and the evolution of the product manager. Journal of Product and Brand Management, 4(3), 49-60. 
Lamey, L., Deleersneyder, B., Dekimpe, M. G., \& Steenkamp, J. E. M. (2007). How business cycles contribute to private label success: Evidence from the United States and Europe. Journal of Marketing, 71(1), 1-15.

Romanelli, E., \& Tushman, M. L. (1994). Organizational transformation as punctuated equilibrium: An empirical test. Academy of Management Journal, 37(5), 1141-1166.

Tushman, M., \& Romannelli, E. (1985). Organizational evolution: A metamorphosis model of convergence and reorientation. In L. L. Cummings \& B. M. Shaw (Eds.), Research in Organizational Behaviour, (7), 171-222. Greenwich, CT: JAI Press.

Table 1. Analysis of USA Private Label Historical Trends $(1840$ - 1950) in the Context of Punctuated and Gradualist Evolutionary Theories

\begin{tabular}{|c|c|c|c|c|}
\hline Year(s) & $\begin{array}{l}\text { Description } \\
\text { of Private } \\
\text { Label Share } \\
\text { Trend } \\
\end{array}$ & $\begin{array}{l}\text { Theoretical } \\
\text { Classification }\end{array}$ & Cause of Trend & Theoretical Explanation \\
\hline $1840-1860$ & $\begin{array}{l}\text { Emergence } \\
\text { (most } \\
\text { probably } \\
\text { rising) }\end{array}$ & $\begin{array}{l}\text { Inconclusive } \\
\text { (inadequate } \\
\text { historical } \\
\text { data) }\end{array}$ & $\begin{array}{l}\text { Entrepreneurial } \\
\text { activity (pride } \\
\text { of ownership) } \\
\text { (Fitzell, 1998) }\end{array}$ & Inconclusive (inadequate historical data) \\
\hline 1861 & $\begin{array}{l}\text { Begins to } \\
\text { decline } \\
\text { (against the } \\
\text { background } \\
\text { of sudden } \\
\text { increased } \\
\text { demand for } \\
\text { national } \\
\text { brands) }\end{array}$ & $\begin{array}{l}\text { Punctuated } \\
\text { change } \\
\text { (falling) }\end{array}$ & $\begin{array}{l}\text { Improved } \\
\text { economic } \\
\text { situation and } \\
\text { transport } \\
\text { systems; } \\
\text { innovation } \\
\text { involving } \\
\text { national, press } \\
\text { advertising } \\
\text { (Herstein and } \\
\text { Gamliel, 2004) }\end{array}$ & $\begin{array}{l}\text { Elements of the underlying order (deep } \\
\text { structure) affected: - market(s), resources, } \\
\text { technology. } \\
\text { Revolution: - improved economy triggers } \\
\text { significant switch in consumer choice to } \\
\text { manufacturer brands due to higher } \\
\text { disposable incomes. Improved transport } \\
\text { systems and advertising-related innovation } \\
\text { promote national distribution and effective } \\
\text { promotion. } \\
\text { New underlying order defining next } \\
\text { equilibrium: - Transformed business } \\
\text { strategy and new consumer mindset. }\end{array}$ \\
\hline $1861-1928$ & $\begin{array}{l}\text { Downward } \\
\text { trend }\end{array}$ & $\begin{array}{l}\text { Probably } \\
\text { gradual } \\
\text { (falling) }\end{array}$ & $\begin{array}{l}\text { Continued } \\
\text { effects of the } \\
\text { above } \\
\text { environmental } \\
\text { perturbations } \\
\text { and the resultant } \\
\text { new equilibrium }\end{array}$ & Consumer and institutional inertia. \\
\hline 1929 & Begins to rise & $\begin{array}{l}\text { Punctuated } \\
\text { change } \\
\text { (rising) }\end{array}$ & $\begin{array}{l}\text { Great } \\
\text { Depression of } \\
1929 \text { (Herstein } \\
\text { and Gamliel, } \\
\text { 2004) }\end{array}$ & $\begin{array}{l}\text { Elements of underlying order affected: - } \\
\text { market(s) and resources. } \\
\text { Revolution: - economic turmoil triggers } \\
\text { significant switch in consumer choice to } \\
\text { retailer brands due to low disposable } \\
\text { incomes. } \\
\text { New underlying order defining next } \\
\text { equilibrium: - Adjusted business strategy } \\
\text { and new consumer mindset (preference for } \\
\text { retailer brands). }\end{array}$ \\
\hline $1929-1945$ & Upward trend & $\begin{array}{l}\text { Probably } \\
\text { gradual } \\
\text { (rising) }\end{array}$ & $\begin{array}{l}\text { Continued } \\
\text { effects of the } \\
\text { above } \\
\text { environmental } \\
\text { perturbations } \\
\text { and the resultant } \\
\text { new equilibrium }\end{array}$ & $\begin{array}{l}\text { Continued effects of institutional and } \\
\text { consumer inertia. }\end{array}$ \\
\hline
\end{tabular}




\begin{tabular}{|c|c|c|c|c|}
\hline 1946-1950s & Stabilising & $\begin{array}{l}\text { Punctuated } \\
\text { change (from } \\
\text { an upward } \\
\text { trend to a } \\
\text { state of } \\
\text { stability) }\end{array}$ & $\begin{array}{l}\text { End of World } \\
\text { War 2, followec } \\
\text { by economic } \\
\text { recovery, } \\
\text { growth of } \\
\text { suburban } \\
\text { middle class, } \\
\text { and diffusion of } \\
\text { commercial } \\
\text { television } \\
\text { (Herstein and } \\
\text { Gamliel, 2004) }\end{array}$ & $\begin{array}{l}\text { Elements of underlying order affected: - } \\
\text { market(s); resources; technology; culture } \\
\text { Revolution: - economic improvement } \\
\text { promotes recovery of national brands due to } \\
\text { higher disposable incomes. Growth of } \\
\text { television technology as an advertising } \\
\text { medium transforms the culture of doing } \\
\text { business. } \\
\text { New underlying order defining next } \\
\text { equilibrium: - Transformed business } \\
\text { strategy (promotion-wise) and new } \\
\text { consumer mindset (product/ brand }\end{array}$ \\
\hline
\end{tabular}

Source: Created for this article based on the literature and theory.

Table 2. Analysis of UK (1962-2005), USA (1982-2005), Australia (1987-2005) and New Zealand (1992-2005) Private Label Share Trends in the Context of Punctuated and Gradualist Evolutionary Theories

\begin{tabular}{|c|c|c|c|c|}
\hline $\begin{array}{l}\text { Country } \\
\text { and Year(s) }\end{array}$ & $\begin{array}{l}\text { Description of } \\
\text { Private label Share } \\
\text { Trend }\end{array}$ & $\begin{array}{l}\text { Theoretical } \\
\text { Classification }\end{array}$ & Cause of Trend & Theoretical Explanation \\
\hline \multicolumn{5}{|l|}{ UK } \\
\hline $1964 / 1965$ & $\begin{array}{l}\text { Steeper upward trend } \\
\text { begins (in } \\
\text { comparison to } \\
\text { previous five years) }\end{array}$ & $\begin{array}{l}\text { Punctuated } \\
\text { evolution } \\
\text { (rising) }\end{array}$ & $\begin{array}{l}\text { Abolition of RPM } \\
\text { (Resale Price } \\
\text { Maintenance) } \\
\text { (Fernie and Pierrel, } \\
\text { 1996; Herstein and } \\
\text { Gamliel, 2004) }\end{array}$ & $\begin{array}{l}\text { Element(s) of underlying } \\
\text { order (deep structure) } \\
\text { affected: - products; } \\
\text { distributions of power. } \\
\text { Revolution: - Abolition of } \\
\text { RPM triggers launch of } \\
\text { retailer brand development } \\
\text { on a large-scale due to shift } \\
\text { in power relations to food } \\
\text { retailers (no longer obliged to } \\
\text { follow stipulated selling } \\
\text { prices). } \\
\text { New underlying order } \\
\text { defining next equilibrium: - } \\
\text { Transformed strategy } \\
\text { (product and pricing); } \\
\text { empowered retailers. }\end{array}$ \\
\hline $1965-1974$ & $\begin{array}{l}\text { Consistent upward } \\
\text { trend at } \\
\text { approximately one } \\
\text { percentage point per } \\
\text { year }\end{array}$ & $\begin{array}{l}\text { Gradual } \\
\text { evolution } \\
\text { (rising) }\end{array}$ & $\begin{array}{l}\text { Transformed } \\
\text { strategy and } \\
\text { empowered } \\
\text { retailers. Later on, } \\
\text { recession. }\end{array}$ & Institutional inertia. \\
\hline 1975 & Share stabilises & $\begin{array}{l}\text { Punctuated } \\
\text { change (from } \\
\text { rising to stable) }\end{array}$ & $\begin{array}{l}\text { Generics failing to } \\
\text { make an impact } \\
\text { (Fernie and Pierrel, } \\
\text { 1996) }\end{array}$ & $\begin{array}{l}\text { Elements of underlying order } \\
\text { affected: - products } \\
\text { Revolution: - precipitated by } \\
\text { weak product policy }\end{array}$ \\
\hline $1975-1979$ & Stable (no change) & $\begin{array}{l}\text { Period of } \\
\text { stability }\end{array}$ & $\begin{array}{l}\text { Generics failing to } \\
\text { make an impact } \\
\text { (Fernie and Pierrel, } \\
\text { 1996) }\end{array}$ & $\begin{array}{l}\text { No change to underlying } \\
\text { order. }\end{array}$ \\
\hline 1980 & Upward trend begins & $\begin{array}{l}\text { Punctuated } \\
\text { evolution } \\
\text { (rising) }\end{array}$ & $\begin{array}{l}\text { Private label } \\
\text { product and } \\
\text { packaging } \\
\text { innovation; } \\
\text { production of }\end{array}$ & $\begin{array}{l}\text { Elements of the underlying } \\
\text { order affected: - products; } \\
\text { technology; organisational } \\
\text { culture. } \\
\text { Revolution: - innovation }\end{array}$ \\
\hline
\end{tabular}




\begin{tabular}{|c|c|c|c|c|}
\hline & & & $\begin{array}{l}\text { up-market private } \\
\text { labels }\end{array}$ & $\begin{array}{l}\text { policy and innovative } \\
\text { activities improve private } \\
\text { label performance. } \\
\text { New underlying order: - } \\
\text { policy on innovation and } \\
\text { quality improvement. }\end{array}$ \\
\hline $1980-1990$ & $\begin{array}{l}\text { Upward trend } \\
\text { continues }\end{array}$ & $\begin{array}{l}\text { Gradual } \\
\text { evolution } \\
\text { (rising) }\end{array}$ & $\begin{array}{l}\text { Private label } \\
\text { product and } \\
\text { packaging } \\
\text { innovation; } \\
\text { production of } \\
\text { up-market retailer } \\
\text { brands }\end{array}$ & $\begin{array}{l}\text { New underlying order that } \\
\text { supports and promotes } \\
\text { innovation and quality } \\
\text { upgrading }\end{array}$ \\
\hline 1991 & $\begin{array}{l}\text { Steeper upward trend } \\
\text { begins }\end{array}$ & $\begin{array}{l}\text { Punctuated } \\
\text { evolution } \\
\text { (rising) }\end{array}$ & $\begin{array}{l}\text { More aggressive } \\
\text { innovation on the } \\
\text { part of private label }\end{array}$ & $\begin{array}{l}\text { New underlying order } \\
\text { strengthened further; deep } \\
\text { structure factors such as core } \\
\text { competencies probably now } \\
\text { in place }\end{array}$ \\
\hline 1991-1994 & $\begin{array}{l}\text { Steeper upward trend } \\
\text { continues }\end{array}$ & $\begin{array}{l}\text { Gradual } \\
\text { evolution } \\
\text { (rising) }\end{array}$ & $\begin{array}{l}\text { Massive innovation } \\
\text { on the part of } \\
\text { private label; } \\
\text { Multi-tier private } \\
\text { label strategy }\end{array}$ & $\begin{array}{l}\text { Effects of new underlying } \\
\text { order }\end{array}$ \\
\hline 1995 & Share stabilises & $\begin{array}{l}\text { Punctuation } \\
\text { (stable) }\end{array}$ & $\begin{array}{l}\text { Probable market } \\
\text { saturation }\end{array}$ & $\begin{array}{l}\text { Underlying order element } \\
\text { affected: - market(s) }\end{array}$ \\
\hline $1995-2005$ & $\begin{array}{l}\text { Share stabilises, falls } \\
\text { and stabilises }\end{array}$ & $\begin{array}{l}\text { Stable; } \\
\text { punctuated } \\
\text { (falling); then } \\
\text { stable again }\end{array}$ & $\begin{array}{l}\text { Probable market } \\
\text { saturation; } \\
\text { Also, competition }\end{array}$ & $\begin{array}{l}\text { Market forces (deep structure } \\
\text { element probably stretched to } \\
\text { the limit) }\end{array}$ \\
\hline \multicolumn{5}{|l|}{ USA } \\
\hline 1982 & $\begin{array}{l}\text { Reversal of trend } \\
\text { (starts to decline) }\end{array}$ & $\begin{array}{l}\text { Punctuated } \\
\text { evolution } \\
\text { (falling) }\end{array}$ & Easing of recession & $\begin{array}{l}\text { Economic improvement } \\
\text { promotes recovery of } \\
\text { national brands }\end{array}$ \\
\hline $1982-1988$ & Downward trend & Gradual & $\begin{array}{l}\text { Limited private } \\
\text { label innovation } \\
\text { and positive impact } \\
\text { of economic } \\
\text { improvement on } \\
\text { national brands }\end{array}$ & $\begin{array}{l}\text { No change to underlying } \\
\text { order }\end{array}$ \\
\hline 1989 & $\begin{array}{l}\text { Reversal of trend } \\
\text { (starts to rise slowly) }\end{array}$ & $\begin{array}{l}\text { Punctuation } \\
\text { (rising) }\end{array}$ & $\begin{array}{l}\text { Product and } \\
\text { packaging } \\
\text { innovation (though } \\
\text { not to the level of } \\
\text { the UK) }\end{array}$ & $\begin{array}{l}\text { Change in underlying order- } \\
\text { shift in policy regarding } \\
\text { private label innovation. New } \\
\text { underlying order in place - } \\
\text { promotes upgrading of } \\
\text { private label quality. }\end{array}$ \\
\hline $1989-2005$ & Steady rise & Gradual (rising) & $\begin{array}{l}\text { Product and } \\
\text { packaging } \\
\text { innovation; } \\
\text { investment in } \\
\text { information } \\
\text { technology }\end{array}$ & $\begin{array}{l}\text { Effects of new underlying } \\
\text { order }\end{array}$ \\
\hline \multicolumn{5}{|l|}{$\mathbf{A U}$} \\
\hline $1987-2005$ & $\begin{array}{l}\text { Fluctuating around } \\
\text { the } 10 \% \text { mark for } \\
\text { almost two decades }\end{array}$ & Probably stable & $\begin{array}{l}\text { A combination of } \\
\text { consumer inertia } \\
\text { and limited private } \\
\text { label development }\end{array}$ & $\begin{array}{l}\text { No major changes to internal } \\
\text { and external environment to } \\
\text { precipitate revolutionary } \\
\text { punctuation }\end{array}$ \\
\hline
\end{tabular}




\begin{tabular}{|c|c|c|c|c|}
\hline $\mathrm{NZ}$ & & & & \\
\hline $1992-1996$ & Steady upward trend & $\begin{array}{l}\text { Gradual } \\
\text { evolution } \\
\text { (rising) }\end{array}$ & $\begin{array}{l}\text { Private label } \\
\text { development }\end{array}$ & $\begin{array}{l}\text { Private label policy shift } \\
\text { (change in deep structure) } \\
\text { facilitates more } \\
\text { organisational support for } \\
\text { own brands }\end{array}$ \\
\hline 1997 & Stabilises & $\begin{array}{l}\text { Punctuated } \\
\text { change } \\
\text { (Absolute } \\
\text { incremental } \\
\text { change of two } \\
\text { percentage } \\
\text { points in five } \\
\text { years vs. slower } \\
\text { absolute gain of } \\
\text { one percentage } \\
\text { point in eight } \\
\text { years) }\end{array}$ & $\begin{array}{l}\text { Inconclusive } \\
\text { (inadequate } \\
\text { historical data) }\end{array}$ & $\begin{array}{l}\text { Inconclusive (inadequate } \\
\text { historical data) }\end{array}$ \\
\hline $1997-2005$ & $\begin{array}{l}\text { Stable and then slow } \\
\text { rise }\end{array}$ & $\begin{array}{l}\text { Gradual } \\
\text { (overall, rising) }\end{array}$ & $\begin{array}{l}\text { Retail } \\
\text { consolidation; } \\
\text { private label } \\
\text { development and } \\
\text { innovation (two-tier } \\
\text { private label } \\
\text { architecture) }\end{array}$ & $\begin{array}{l}\text { Elements of the underlying } \\
\text { order affected: - power; } \\
\text { organisational structure; } \\
\text { strategy. New underlying } \\
\text { order supports private label } \\
\text { development (e.g. private } \\
\text { label policy on innovation } \\
\text { and management). Structure } \\
\text { keeps improving; formation } \\
\text { of Foodstuffs Own Brands } \\
\text { Limited in 2003; more } \\
\text { resources to support sourcing } \\
\text { of own brands. }\end{array}$ \\
\hline
\end{tabular}

Source: Created for this article based on the literature and theory. 